\title{
ANTIBIOTIC RESISTANCE OF BACTERIA IMPLICATED IN URINARY TRACT INFECTIONS IN DLABETIC WOMEN
}

\author{
Mansour, F. A. *; Ghall, M. F.** \\ and El-Kenawy, A. Zeinab \\ Dotany Department Faculty of Scienre, Mansoura University* \\ Botany Dcpartment Faculty of Science. Zagazig University*"
}

\begin{abstract}
Urinary tract infections are amongst the most common pathogentic infections with cun increasing resistence to anduricrobials. Isolates from urine samples were identified and their susceptibility to antimicrobial agen's were studled, also synergetic and antagonism of the combined antblotics against bacterlal tsolates and electron inicroscope study against multt-drug resistent bacteria were studted. During the study. 211 urine samples from diabetic and non diabettc female patient were antalysed, of which 175 had slenificant bacteriuria (98 from diabetic and 17 from non diabetic). For diabetic pathent, Eschertchia coli was the most common ettologic agent 27 (27.6\%) followed by Serratia 12(12.2\%, Citrobacter, Enterabacter and Mtcrocaci each one was $10910.2 \%)$. Satmonella 777. 1\%), Pseudomonas aeruglnosa and Coagulase negative siaphylococci each one was 6(6.1\%). Proteus 5(5.1\%), Staphylococcus aureus and Shigella each one was 2 (2\%) and Streptocacti 1(1\%), also for non dilabetic patient E.coli was the most conumon etiologic agent 10158.8\% followed by Enterobacter and Proteus each one was 3 (1 7.6\%) and Streptocacd $1(5.9 \%)$. Also we studled the relattonship between percentoge of infection and age of pattents. Amlkacin. chprofloxacin and norflaxacin expressed the most effectloe antbioutes on these tsolates but all these tsolales were resistent to anpicillin/ sulbactam, enythomycin, amoxiculn flomocin clavudanic acld and piperacillin except Salmoxtella was sensitive to amoxicillin flomoctn clavulanic acid and Enterobacter was sensithle to piperacillin, the combination between ciprofloxarin and cefotaxim sadum is the most one which showed synerget agatnst bacterlal tsolates followed by clprofloxacin and amlkacin and amlkacin and nilnofurantion. Pseudonwonas oenginosa uxas re. sistent to all antblotic which used but showed synergetic agalist the combination between clprofloxacin and amdkachn, ciproflakach and norfloxach, norjloxacin and anklkacin and anikacin and nlirafiurantion, also. the cell of Pseudorronicas aeruginosa appear normal under electron microscape when nat treated wth norflaxacin but when treated whth norfloxactin the cell become bonger.
\end{abstract}




$$
\begin{aligned}
& \text { الللنضص العربي } \\
& \text { متارئة البكتريا المسنولّ عن إمابات المهاز البولى التناسلى للمضادات البكتيرية }
\end{aligned}
$$

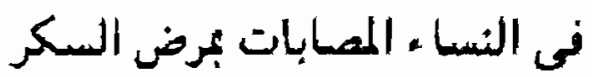

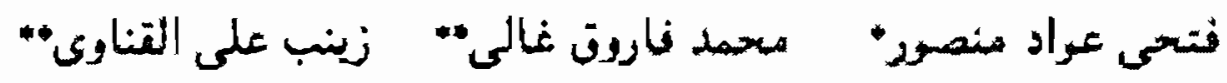

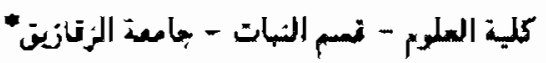

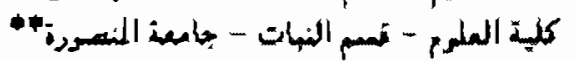

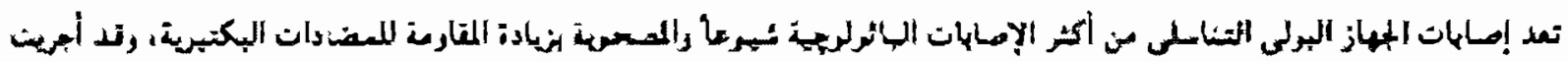

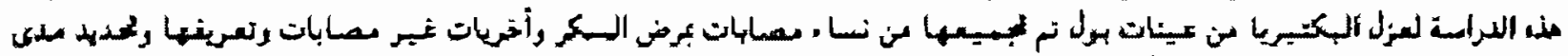

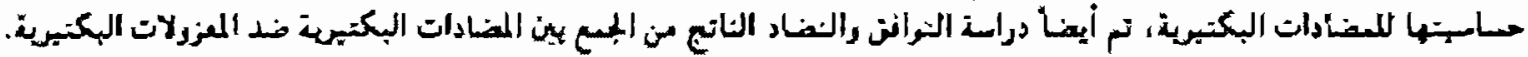

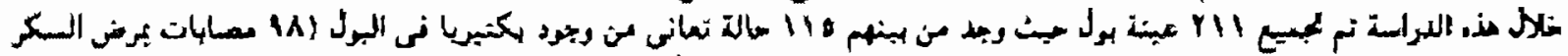

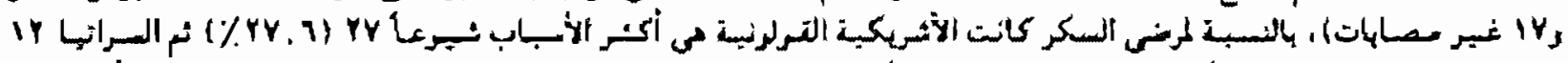

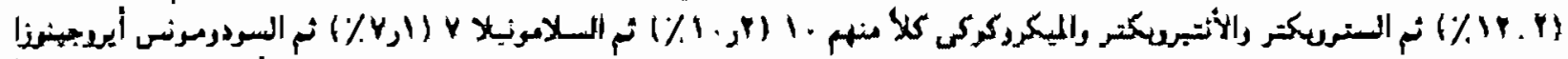

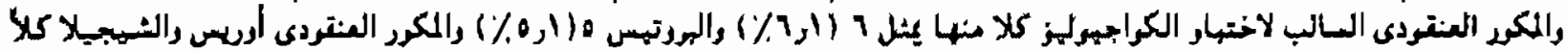

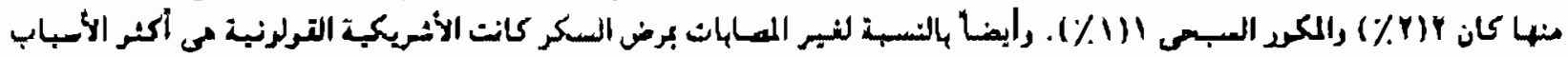

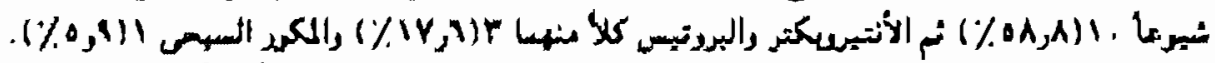

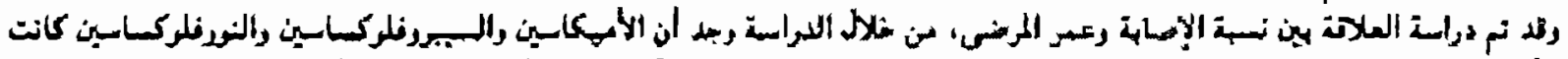

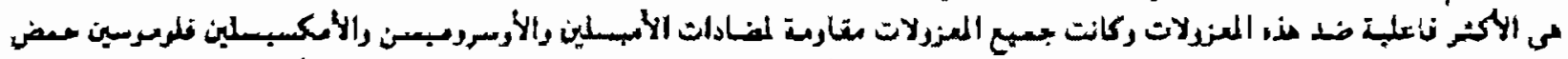

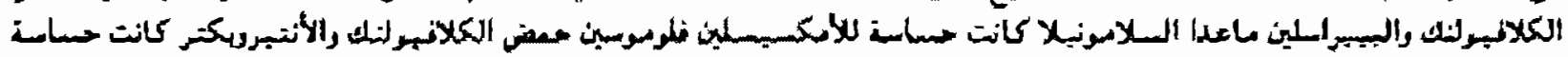

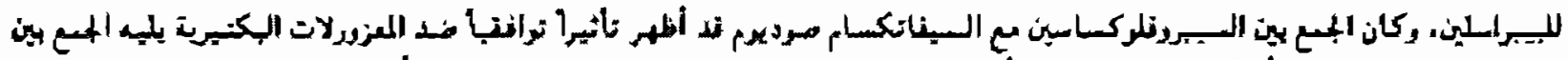

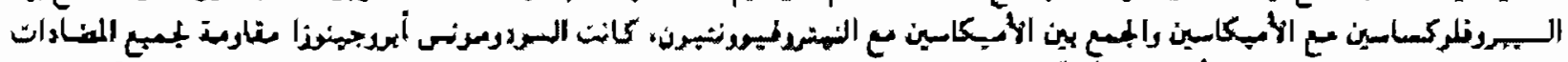

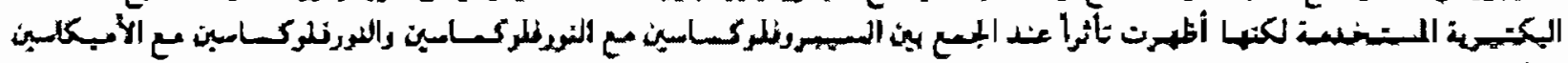

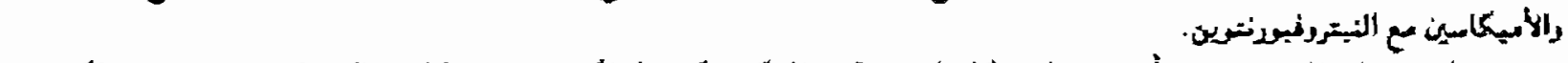

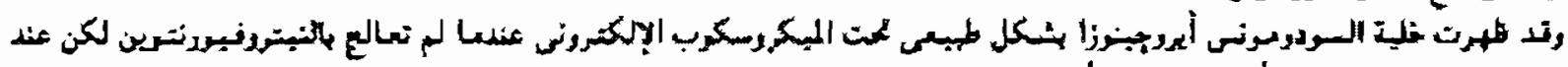

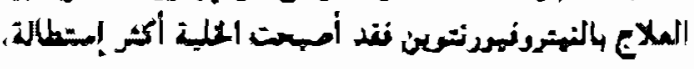

\section{INTRODUCTTON}

Infections of the urinary traet are the second most common type of infection in the body. Urinary track infectuons (UThs) aecount for about 8.3 millifon doctor visits each ycar. Women are espectally prone to UII. One woman is thve develops a UTT durtng her lifeUme.

During any given year. 11 percent of worn- en report had a urinary tract infection. and more than half of all women have at least one such infoction during their lifeumetFoxman et al 2000).

Unnary tract infection (UTI) is a bactertal infection that aflects any part of the urtnary tract . Normally, urine is sterle and It to usually free of bacterla. ruruses, and fung because it contains a vartety of nuids. salts, and 
waste products but the Infection occurs when any organisms, usually bacterla from the dlgestive tract. cling to the opening of the urethra and begin to multiply, the most of these organisms to Eschertehla coll (E. coll), which nombally lives in the colon, in addition to E.coll ,other organisms such as Kjebotella spp. Proteus spp. Enterobacter spp. Cltrobacter spp. Salmonella other Enterobactertaceae, Staphylococcus app. Streptococcl, enterococel and Pseudomonas spp may be involved . In most cases bactera travel to the urethra and muluply caustag urethra Infection (urethritis) and If the bacterla move to the bladder and muluply, a bladder infection (cystitls) can occur, if the infection is not treated promptly. bacteria may thcn travel further up the ure. ters to multiply and reach to the kldneys causing kJdney Infection (pyeloncphrits) whtch ts much more sertous because it leading to kidneys damaged if a Um to not treated for months or years. The urinary system is gtructured in a way that helps ward off infectuon in which the ureters and bladder normally prevent urine from backing up toward the kddrueys and the now of urine from the bladder helps wash bacterla out of the boxly (Meyholl et al 1981. Jepson et al 2000, Lza et al 2003. Bethesda 2005 \& Dawd et al 20081 .

Pseudo-monas specles which caused UTT are known to be assoctated with hospltal infections ( Hulf et al 1989 Goetz and Yu 1997). Sexual intercourse is thought to racuItate migration of the organisms from the urethra into the bladder before Initiation of infecton (Buckely etal 1978 \& Nicolle etal 1982).

Urinary tract tnfections (UTls) are charac- tertzed as being elther upper or lower based primarly on the anatomic location of infeetlon : the lower urinary tract encompasses the bladder and urethra, and the upper urinary tratet encompases the ureters and kidneys. The anatomy of the female urethra is of parteular importance to the pathogenesis of UTis as it is relatively short compared with the male urethra and also lics in cluse proxdmity to the warm , molst , pertrectal reglons, which Is mectung with microorgantsms. Because of the shorter urethra, bacterta can reach the bladder more easily in the female host (Betty et al (1998).

Urinary tract bacterial infecton are common In women. Moreover, they tend to recur through out life cspeclally with irequent sexual activity, pregnancy, stones disease or diabctes (Jeanne and F.Gary 2005).

Most infections in diabetic patuents are located in the urtrary tract and in diabetlc wornen. these infectlons occur frequently. can have a complicated course, are more difflucult to treat and often recur than non diabetc patient because of the multuple effects of the disease on the urnary traet and host Immune system (Vejlagaard :966. I. M. Hoepelman 1994 \& Patterson and Androle 1997 .

Several types of urtnary tract infectlons oc cur more commonly in diabetic patients and these include Increasing in clinical severity. asymptomatic bacteriuria, cyotuss, emphysematous cystitls, pyelonephritus and emplysematous pyelonephrits and perinephrtc abscess, emphysemalous infections refer to those complicated by gas tormation due to 
bactertal fermentation and this may occur in the bladder (cysulus) or in the renal pelvis or parenchyma (pyelonephritis) (Ankel et a) 1990).

Urinary tract infectlons (UTT) are very often encounted in patlents with dlabetes mcllitus. They may preseist theinselves as asyniplomatIc bacterturla, but may also led to more serious infection. Asymptomatic bacteriuria is more prevalent in women, but no men, with dlabetes mellitus compared to conurols. The Inereased prevalence of UTts in diabetic pathents can be the result of diliterences in the host responses between dlabeuc and non diabette patients, or a difference in the infecting bacterium itself. the bacterla causing UTls in dlabetic pattents are the same as in eomplcated UTls in non dlabetlc pallents. E. coll is the most common causative microorganlam. Kiebsiella, Entrobacter, Serratta spp. and streptoceous faecalls have been Isolated (1. M. Hoepelman 1984).

A common source of Infection is catheters. or tubes placed in the urethra and bladder. A person who cannot vold or who is unconeclous or critlcally ill ofen needs a catheter that stays in place for a long tume. Some people especially the elderly or those with nervous systern dlsorders who lose bladder control. may need a calheter for life. Bacteria on the catheter can Infect the bladder. People with dlabetes have a higher riak of a UTI because of changes in the tmmune system. Any other disorder that suppresaes the Immune system ralaes the risk of urinary infection. According to several studles, women who use a diaphragm are more likely to develop a ITT than women who use other forms of birth control (Bethesda 2005).

Antimicroblals such as ptperaclllin should be considered emplric antiblotie for catheterassoclated UTYs and these agent have activity agalnst many noscomially acquired Gramnegatuve rods, Ineluding P.aeruginosea Moellerting 1998).

Trimethoprim-sulphamethoxazole was recommended as initlal therapy of UM. but only in communities where prevalence of trimethoprim- sulphamethoxazole reglatence is less than $20 \%$ (J.W.Warren et al 1999).

The antimicroblal agent with the highest levels of activity against Gram-negative bacillt was amikactn which was restricted to hospital use whlle ciprolloxactn and nltrofurantoln Bhowed aeceptable levels of aetdity . Nitrofurantoin was acllve agalnst all strains of S.aureus but there is a reduction th the activIty of amoxyellin with clavulanate and quino. lones to Ecoll. (Rose et al 2001).

\section{MATERTALS AND METHODS}

Two hundred and eleven dkabetlc and non diabetic cases were subject to this study and admitted public hospital and kdoney center at Mansoura. Ages of cases were ranged from 20 to 70 years. This study was done over a pert. od of one year.

Urtne samples are most commonly collected by sampling the mid stream flow by the clean - catch technique (Bradbury 1988). Once collected, a specimen of urine must be transported to the laboratory with- out delay JJ. A. Porter and J.Brodle 1969) . 


\section{DISCUSSION}

Thls study shaws the distribution of bacteria isolated from patient with urinary tract iniection and thefs ausceptiblity pattern to ants. biotics.

Escherichla coll was rceponsible for about 65. 1\% of urnasy tract infcctoon in different parts of Britain where as other colijorms than E. coll were 23.4\% , 4.6\% Froteus and Morg nella spp., 1.8\% Pseudomonas spp., 2.496 enterococcl, $0.7 \%$ group B streptococel, $1.5 \%$ cozulase-negative staphyloconct and $0.5 \%$ Staphylococcus aureus. (S. P. Barrett et al 1999).

The frequency of E.coll In urne samples varies in different studies from $32 \%(\mathrm{~K}$. okada et al 1994) to intermediate values $40 \%$ (F.A.arret and S.M.ehurland 1998). to 86\%61 Gupta el al 1999 J.c.Nunezsanchez et al 1999), to 65\% (J.C.Nunezsanchez et al 1999 \& S.P.Barrett et al 1999). A result in Spaln was 474 $\Omega$ with the prevlous result (Rosa at al 2001).

E.eoll was the predominant causative agent 27 (27.6\%) and 10(58.8\%) for dlabetic and non diabetic wamen respectuely followed by Serratta 12(12.2\%), Citrobacter . Enternbacter and Microeoces each one was 10 (10.2\%), Salmonella 7(7.1\%). Pseudomonas aenuginosa and Coagulase negatuve staphylocacel eaeh one was 6(B.1\%) , Eroteus 5 (5.1\%) . Staphylococcus aureus and Shigella each one was 2(2\%) and streptococcl 1(1\%) for dlabetic women but for non dlabette women It was followed by Enterobacter and Proteus each one was 3(17.6\%) and Streptococel ] [5.9\%) .
In this study we found that the ineldance of bacteriuria was higher among diabetic women ages 41 to $50(70.5 \%)$ and thls probability decrease by 3.8 th with age 31.40 (66.7 76 ) and the less incidence was among age of $20-30$ (20\%) whlch agree with those demonstrated by Nicollc et al who found that both men and women with diabelea have an increased risk of acute pyelonephritls requiring hospltal admission. In a recent study. dlabetes was estmated to increase thils probabllity 20 to 30 lold under the age of 44 and three to five fold over the age of 44 (Nicolle et al 1996).

But the Incidence of bacterturla was hlgher among non dlabetk women ages 61.70 (7).4) and this probabllity decrease by $17.6 \%$ with age 20-30 year $(53.8 \%)$ and the less ineidence was among age of 41-50 and 51-60 . both were $0 \%$ which disagree with those demonstrated by Betty et al. 1998 and Geo.f. Brooks et al who found that the Incldence of bacterturta arnong girls age 5 through 14 is 1\% to $2 \%$. This Inctdence Increases to $5 \%$ in girls over age 10 . The prevalence of bacterturia In females increases gradually with time to as high as $10 \%$ to $20 \%$ in elderly women. In women between the ages af 20 and 40 whom have UTIs , as many as $50 \%$ may becorne reInfected with 1 year. The association of UIls with sexual Intercourse may also contribute to this tncreased inctdence because sexual aeuvity serves to increase the chances of bacteral contanination of the female urethra (Betty et al 1998).

Pipereillin is effectlve agalnst more than $80 \%$ of Preudomonas aeruginasa stralns (Ailan Ronald 1984 and Mocllering 1998 ) which 
dlsagree whith our results whlch showed that Pyperclilin is resigtant agalnst Pseudomonas aeruginosa.

Proleus spp , Citrobacter spp and Pseudomonas aeruginosa showed resistance to clpro. flaxacin ( Huf et al 1989 Coetz and Yu 1997) which agre whth our results which showed that Proteus. Cltrobacter and Pseudomonas aeruglnosa were registant to clpro floxacin and disagree with other results which showed that efprofloxacin is the most active afalnst Pseudomonas species (O'Donnell and Getonc 2000).

Nitriurantoln showed an acceptable level of activity agalnst Proteus spp and non lermenting Gram-negatlve bacllis (D.Wolday and W.Erge 1997) which agree with our results whlch showed that nitrolurantlon was senslUve againgt Protcus. NItrofurantoln was acUve against all strains of S.aureus (Rosa ct al 2001) whish disagree with our regults which showed that Nltrolurantoln was reslotant agalnst Staphyloraccus aureus .

Nitrofurantoin has no actrity against Pseudomonas aeruginosa (Judith et al 2002) which agree with ours.

The E. coll showed high rates of reststance to amoxdellin, amoxdcilinn-clavulanate and ciprofloxacin (Kader et al 2000) whtch agree with our results which showed that anoxtclllin-clavulanate to resistant agalnst E.coli but dlaggree with our as etprofaxactn was senstthe agalnat E.coll . The E,coll lsolntes were susceptble to nltrofurantoln and clprofloxacin but resistant to ampicillin and trimethoprim (Leonid and Vladimir 2006) which agree with ours except that nitrofurantion was re sistant.

The combinatlon betwecn clprofloxaeln and celotaxim sodlum show the higher synergettc activity against bacterial isolates followed by the comblnation between amikacin and nitrofurantion and the combination between amlkacin and esproflaxacin .

Peudomonas aeruginosa was restitant agatnst all antblouc tested so we examined it under electron microscope after and bcfore treated with norfloxacin and the cell appear normal when not treated but when treated the cell beeome longer. 
Table (1): The frequency of the bacterial isolates from positive collected samples of diabetie females.

\begin{tabular}{|c|c|c|}
\hline Bacterial isulates & Count & Frequency \\
\hline E.coli & 27 & $27.6 \%$ \\
\hline Citrobacier & 10 & $10.2 \%$ \\
\hline Enterabacter & 10 & $10.2 \%$ \\
\hline Salmanella & 7 & $7.1 \%$ \\
\hline Serratia & 12 & $12.2 \%$ \\
\hline Shigella & 2 & $2 \%$ \\
\hline Pseudomonas aeruginosa & 6 & $6.1 \%$ \\
\hline$\overline{\text { Proteus }}$ & 5 & $5.1 \%$ \\
\hline Co-agulase negative staphylococci & 6 & $6.1 \%$ \\
\hline Micrococci & 10 & $10.2 \%$ \\
\hline Staphylococcus aureus & 2 & $2 \%$ \\
\hline Streptococci & $\overline{1}$ & $1 \%$ \\
\hline Total & 98 & $100 \%$ \\
\hline
\end{tabular}

Cbi-Square Value $=70.5 \quad$ P Value $=0.0001$

$$
\text { Frequency }=\frac{\text { Positive samples }}{\text { Total samples }} \times 100
$$

Table (2): The frequency of the bacterial isolgtes from positive colleeted samples of non diabetic females :-

\begin{tabular}{|c|c|c|}
\hline Bacterial isolates & Count & Frequeney \\
\hline E.coli & 10 & $58.8 \%$ \\
\hline Enterobacter & 3 & $17.6 \%$ \\
\hline Proteus & 3 & $17.6 \%$ \\
\hline Streptocacci & 1 & $5.9 \%$ \\
\hline Total & 17 & $100 \%$ \\
\hline Chi-Square Value $=14.7$ & & PValue $=0.002$ \\
\hline
\end{tabular}


Table (3) : Inhibition zone (mm) of dtfferent pathogenic bacterial isolates against different lested antibiotic.

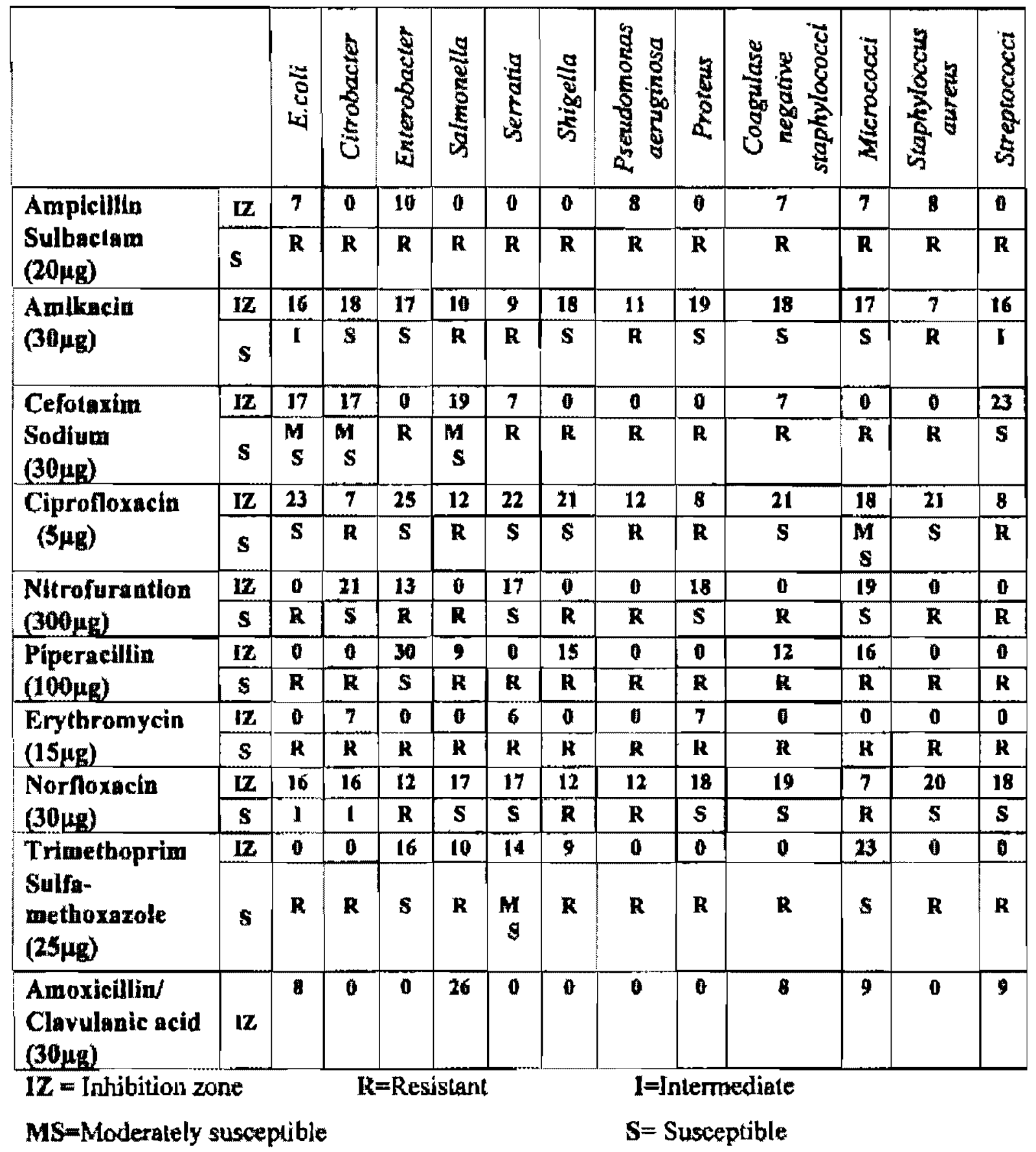


Fig (1) : Bacterial culture of arine samples collected from diabetic and non diabetic remale patients of differcnt ages.

Diabetic

$\square$ Non diabetic

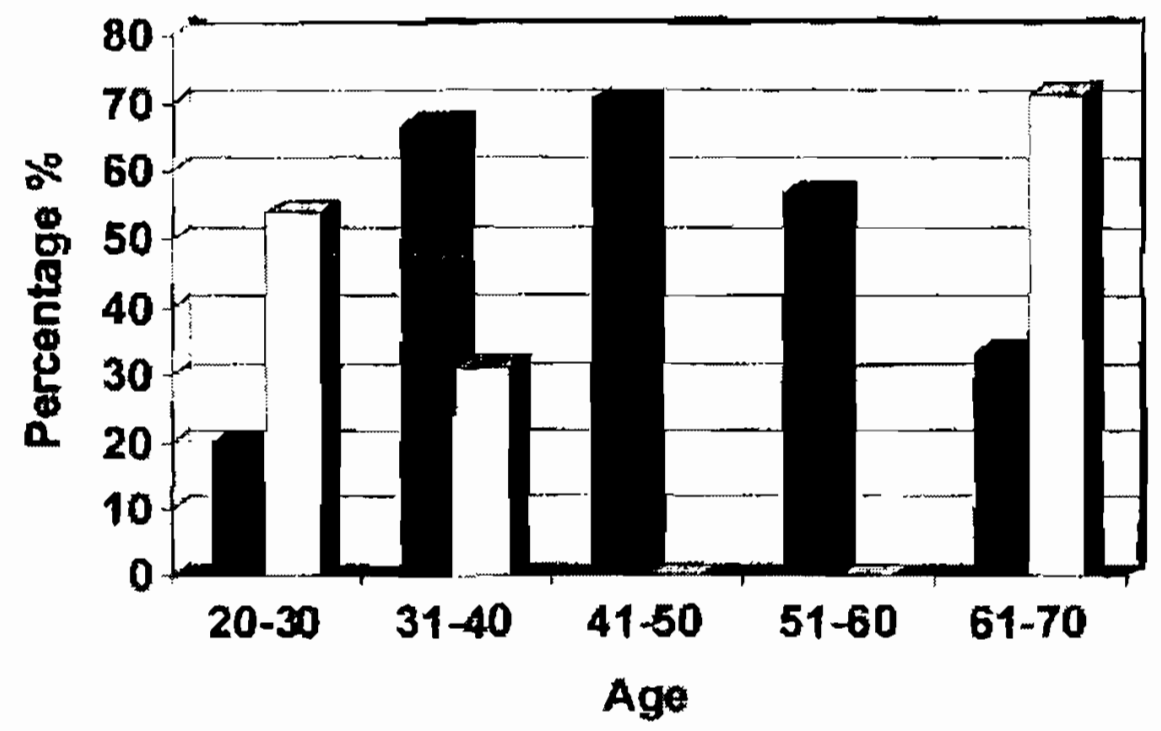




\section{REFERENCES}

Allan, R. Ronald (1984) : Current concept In the management of ururary Lacl infoctlon in Adults. Medieal clinis of North America. vol. 68., No.2.

Ankel, F.; Wolison, A B and stapczyn.4. J, 8. (1800) : Emphysematous cysutus: A complication of urinary tract infection occurring predomlnantly in dlabetic women. Ann Emerg. Med. 19:404-406 .

Barron, E. J. O.; Peterwon, L, R. and Finegold, 8. M. (1904) : Enterobactertaceae In Barron, E.J.O; Peterson, L. R. and Finegald, S. M (eds) : Balley and Scatt's Dlagnostic Microblology, 362-395. Inc, Missurt.

Baver, A. W.: EIrby, W. M.; Bherrle, J. C. and Turk, M. (1088) : Anublotic suscepubilIty tesung by standardized single disk methor Am, $J$.of Cl. Pathology: 45:493-496.

Betheeda, M. D. (2005) : National KJdney and Urologlc Diseases Informatlon Clearing houge. NLH. Publication, No. 06 : 2097.

Betty, A. Forbes; Daniel, F. sahm and Allce, B. weles feld (1908) : Dlagnoste mlcroblology. Tenth Edition. Moshy publishing.

Bowden , O. H. W, (1990) : Microblology of root surface cartes in humari. J. Dent. Fes., 69: 1205-1210.

Bradbury, 8. M. (1968) : Collection of urtne spectmens in general practlce : to clean or not to clean ? JR Coll Gen Pract, $38: 363$ 368.
Buckely, R. M.; Mccuchln, M. and ancOregor, R. R. (1878) : Urine bactertal counts alter scxual Inter course. NEngl JMed. 298:321-324.

Cheesbrough, H. (2000) : Micrablological test . In : Cheesbrough. M. (ed) . Distrlet laboratory practice in tropical countries . 1-226. Cambridge Universlty Press . U.K.

D.wolday and w. Erge (1987) : Increased Incldence of reslstance at T1- kur Anbessa Hospltal . Ethlop. Med. J. 35:127-135.

David, \&. Howes: Joenph, A Ealomone; FranclacoTalntera; Rkchard Binert : John . D. Halamka and Pamela, L, Dyre (2008) ; Urinary tract infection. Female. ernedicine from Web MD.

F. A. Orret and 8. M. Shurinad (1998): The changing paljents of antimicroblal suseeptubility of urinary pathogens in trinided. Singapore Med . J. 39:256-259.

Foxman, B.; Barlow, R.; D. Arcy, H.; OAlesple, B. and Bobel, J. D. (2000) : Urtnary tract Infection : sellreperted Incidence and assoclated costs. Ann. Eptdemoll. 10: 509-515.

Goek, A and Yu, V. L. (1897) : yntenstve care unlt : the hottest zone . Curr Opln Infect DIs, $10: 319-323$.

Oupta, E.; Bcholes, D. and Btumm, W. E. (1990) : Inereasing prevalence of antimlcrobla) reslslance among uropathogens causing acute uncomplicated cystutie in women. J. Am. Med. Agsoc . 281:796-738. 
HuY, M.; Yu, V. L.: Sharp, J.; et al., (1089) : Antubiotic therapy for Pseudomonas aeruginosa bacteremla: outcome eorrelations a prospective study or 200 patients. Am J Med. 87: 540-546.

1. M. Hoepelmun (1004) : International Journal of Antmicroblal Afents Vol 4:113116.

J. A. Porter and J. Erodfe (1860) : BorlC acid preservation of urine samples . Br Med J. $10,2(5653): 353-355$.

J. C. Nunezsanchez; M. T. Catala Barce10; 1. Navarto obrer and J. V. Balaquer Marthex (1990) : Tratamlento delas infectiones urinartas en paclentes con factores derlesgo. Med. Clin , 24:558-559.

J. W. Warren; E. Ablutyn; J. R. Hebel; J. R. Johnnon; A. J. Bchneffer and A E. Btamm (1099) : Guldclines for antumicroblal treatment of un complfcated acute bacterial cystlus and acute pyelonephrtes in women. Cinn InTect .Dis. 29:745-658 .

Jeanne, 6. Shefneld and F. Gary Cuaningham (2006) : Urinary tract Infecton in wornen. Obstetrics and Gynecology, 106 : 1085 1095 .

Jepnon, R,; Mihallevic, L. and Cralg. J, (2000) : cranberrles for preventing urinary tract Infections. Cochrane Database Syst Rev :CD001321.PMID149739684http://www.ncbl. ntm.nih.gov/entrez/query.(c-g)).

Judith, A. O'Donnelli Bteven. P. Gelone and Ellus Abrutyn (2002) : Selectung drug regimens for urinary tract infecllans : current recommendatlons. Infect Med 19(1) : 14-22,

K. Okadn; Y. Unui: T. Abe; et al., (1004) : Statisucs studies on bacterla isolated from urinary traet infections. Hinyokıka kiyo, 40: 175-185.

Kadder, A A; Mamalmurzaman, M. and Daso, 6. M. (2000) : Antumlcroblal resistance pattern of microorganlsins isolated from blood cultures in a Saudt Arablan hospltal. BMJME. $7: 6-7$

Koneman, E. W.; Allen, B. D.; Janda, W. A: et al., (1907) : Guldelines for the collecton transport, processing, analysls and reporting of cultures from specific specirnen sources. In : Koneman. E.W; Allen. S.D; Janda. W. A: Schrekenberger, P.C and Wins, JRWC (eds) color atlas and text book of dlagnostdc. Microbtology. 121-162, Lipoincott Raven, Washington .

Loonld, 8. Btratchounsh and Vladimir, V. Fufalat (2006) : Antumlcroblal susceptblllty of pathogens isolated from adult paHents with uncomplicated communityacquired urnary tract Infectlons in the Russlan Fedcration : two multicentre studtes. UTAP-1 and UTLAP-2 International Journal of Antuntcrobial Aetents. Volume 28. Supplement 1, Pagcs 4-9.

Lea Dlleo Thomas; Bcott Hplanth: Francloco Talavera: Mchael Dowtting; Jonathan Aller and James ungas (2003) : urinary tract infection. e Mediclne world Medical Lلbrary from Web MD. 
Marle Tro-Hurdy: Brancls Vanderblat; Hamidou Traore and Mlehel Jean Devlecschouwer (2008) ; In vitro actlvity or antlblotle eombinations against Pseudomonas aeruginoblofin and planktonic cultures. Internatoal Joumal or Antimicroblal Agent, $31: 329$ 336 .

Heyhoff, H.: Nordling, J.; Gammelgaard, P. end Vafteganrd, R. (1081) : Dose anubactertal ointment applied to urethral meatus in women prevent recurrent eysutts ? . Scand $J$ Urol Nephrol 15 [2] : 81-3.PMID 70363392 (http://www.ncbl.nlm.nih.gov/entrez/ query. [icgi).

Moellering , R.C.J.R. (1908) : vancomyen - resiglant entenococeus. Clin Infect Dis , $26: 1196-1199$.

Nicolle, Ln E.; Harding, O. $\mathbf{x}$. M.; Prelkadtin, J. and Ronnd, A. R. (1082) : The assoclation of urlnary tract inicction with sexual Intercourse. J Infeet Dis . 146:574-583.

Ncolle, L E.; Frlesen, D.: Harding, 0. K.; et al., (1006): Hospitalization for acute pyelonephritre In Manitoba . Canada, durng the pertod from 1989 to 1922 , impact of diabetes. pregnancy , andaboriginal orign , elin Infect DIs . 22 (6) : 105I-6.

O Donnell, J. A and Gelore, B. P. (2000) : The FLuoroquinalones . Infect Dls clin. North. Aun, 14:489-513.

Pattereon, J. E. and Andriole, V. T.
(1897) : Bactertal urnary tracl Infections in diabetes. Infect Dts cin North Am , 11 (3) 735750.

Roan Dasa; Joee Ontlerrox and Concalo Pledrole (2001) : Antlbjotlc susceptbility of bacterlal stralns lsolated from patlents with community - acqutred uninary tract infecttons. International Journal of Antimicrobial Agents, 18[3] : 211-215.

8. P. Barrett; M. A. Barage; M. P. Rebec; A Gugot; N. Andrew and B. B. Ehrimpton (1690) : Antibtotic gensluwty of bacterta assoclated whth communily-acogutred urinary tract Infection in Britaln. Joumal of AntImicroblal Chemotherapy, 44, 350-365.

Bmith, A. 2. (1080) : Laboralory Identulcation In microblology and pathology 12th ed. The C.V.Mosby Company st . Lovis . Toronto, Landon . P 68 .

Bonaen with, A. C. (1880) : Gradwohol's Clinical Laboratory Methods and Dlagnosts Vol . 2; 8th ed. Sonnenwrith; $A C$ and Jarett $L$. (eds). The CV Masby Co. London; Tomto.

Vejlegaard R. (1868) : studlea on unnary infection in diabetics. I. bacterturia in patlents with dlabetes mellitus and in control subjects. Acta Med scand. $179: 173-$ 182.

Wolfgang, If J. D.; bulda, P. W.; Bernard, A. D. and Catherlne, M. (1998) : Oral microblology , In Zineser Microbiol 20th edition. 